\title{
Działalność architektoniczna w formie spółki partnerskiej
}

\section{Wanda Misiak}

\author{
STRESZCZENIE \\ W publikacji zwrócona została uwaga na możliwość podjęcia i prowadzenia działalności architektonicznej w for- \\ mie spółki partnerskiej z uwagi na jej specyfikę. Tego typu spółka przeznaczona jest do wykonywania wolnych zawo- \\ dów. Z wykonywaniem wolnego zawodu (w tym zawodu architekta) wiąże się ryzyko popełnienia błędu „w sztuce”, \\ a co za tym idzie obowiązek odszkodowania, które jest zobowiązaniem spółki. \\ W spółce partnerskiej odpowiedzialność za zobowiązanie uwzględnia ryzyko błędu i korzystniej niż w innych \\ spółkach ponoszenie tej odpowiedzialności zostało uregulowane. \\ Podstawowy wniosek zawarty w publikacji, to wskazanie na spółkę partnerska, jako najkorzystniejszą formę wy- \\ konywania działalności architektonicznej.
}

Zgodnie z postanowieniem art. 86 Kodeksu Spółek Handlowych spółką partnerską jest spółka osobowa, utworzona przez wspólników (partnerów) w celu wykonywania wolnego zawodu w spółce prowadzącej przedsiębiorstwo pod własną firmą.

Przed wejściem w życie Kodeksu Spółek Handlowych, czyli dniem pierwszego stycznia 2001 r. tego typu spółka nie funkcjonowała w obrocie gospodarczym w Polsce, w przeciwieństwie do innych spółek regulowanych w Kodeksie Handlowym uchwalonym jeszcze w 1934 r.

Spółka partnerska, jako forma organizacyjno-prawna do prowadzenia działalności gospodarczej, była dużo wcześniej znana w innych krajach. Rozwiązania tam przyjęte były wzorem do ukształtowania podobnych rozwiązań w naszym kraju. Pierwowzorem dla tego rodzaju rozwiązań było ustawodawstwo amerykańskie i w pewnym zakresie niemieckie. Choć trzeba zaznaczyć, że uregulowania zawarte w Kodeksie Spółek Handlowych różnią się w wielu aspektach, jak chociażby w tym, że konstrukcja spółki partnerskiej w polskim prawie nie posiada pełnej osobowości prawnej, w odróżnieniu od innych ustawodawstw, a z tym wiążą się także zasady opodatkowania.

W uregulowaniach Kodeku Spółek Handlowych zawarty został dosyć wąski, w porównaniu z innymi krajami, katalog zawodów, których wykonywanie pozwala funkcjonować w ramach spółki partnerskiej. Jednak zasadniczy problem określający tożsamość spółki partnerskiej, co do zasad odpowiedzialności za jej zobowiązania, został uregulowany tak samo w krajach, w których konstrukcja prawna spółki partnerskiej została przyjęta.

Wzbogacenie katalogu spółek o spółkę partnerska, to bardzo znacząca zmiana w sposobie funkcjonowania podmiotów gospodarczych po roku 1989.

Spółka partnerska, jak to wynika z przytoczonego na wstępie brzmienia art. 86 K.s.h. jest spółką osobowa, a one właśnie stanowią alternatywę dla spółek kapitałowych o innej istocie prawnej. 
Spółki osobowe charakteryzują się tym, że swoją działalność opierają na osobistym zaangażowaniu spółkowiczów, ich umiejętności, zdolności, doświadczeniu zawodowym, a nie na wniesionym do spółki kapitale.

Jest to pierwsza z cech, która powoduje jej atrakcyjność dla tych wspólników, którzy rozpoczynając działalność gospodarczą nie dysponują kapitałem, który można wnieść do spółki tytułem wkładu. Wkładem do spółki osobowej może być praca na rzecz spółki czy wykonywane dla niej usługi. Inaczej niż w odniesieniu do spółek kapitałowych, nie jest określona przez przepisy minimalna wartość wkładu.

W spółkach osobowych wspólnicy razem ze spółką ponoszą pełną odpowiedzialność majątkową za zobowiązania spółki. Odpowiedzialność ta nie jest ograniczona do zainwestowanych środków, a dotyczy odpowiedzialności całym osobistym majątkiem wspólników.

Spośród innych spółek osobowych, spółkę partnerską wyróżnia szereg swoistych cech, które czynią ją atrakcyjną do prowadzenia działalności architektonicznej. Z samego założenia jest ona przeznaczona dla tej grupy przedsiębiorców, gdyż zgodnie z art. $87 \S 1$ partnerem w spółce partnerskiej mogą być wyłącznie osoby fizyczne uprawnione do wykonywania wolnych zawodów, a takim zawodem jest zawód architekta.

Katalog wolnych zawodów wyszczególniony jest w art. 88 K.s.h. i ma charakter ograniczony. W porównaniu z innymi spółkami, których wspólnikami mogą być osoby fizyczne i prawne bez względu na zawód i zakres prowadzonej działalności, ograniczona została konkurencja w obrocie gospodarczym na korzyść spółek partnerskich.

Celem działalności spółki partnerskiej jest wykonywanie wolnego zawodu, czasem więcej niż jednego, bo pozwala na to art. $86 \S 2$ K.s.h.

Spółka partnerska nie ma osobowości prawnej, a jest tzw. „ułomną osobą prawną”, co pozwala jej funkcjonować w obrocie, jako samodzielnemu podmiotowi z uwagi na posiadanie zdolności sądowej, ale jednocześnie taki status prawny wyłączył ją od opodatkowania właściwego dla osób prawnych.

Cechą pozytywną takiego ukształtowania podmiotowości prawnej spółek partnerskich jest wprowadzenie przez ustawodawcę zezwolenia na dokonywanie zmian w składzie osobowym ich wspólników (partnerów). Umożliwia to dokonywanie transformacji podmiotowych w tego typu spółkach, tak jak to ma miejsce w spółkach kapitałowych [Asłanowicz 2004]. Daje to swobodę w ukształtowaniu optymalnego składu osobowego spółki.

Cechą fundamentalną stanowiącą o istocie spółki partnerskiej, a także jej atrakcyjności dla wykonywania wolnych zawodów, w tym zawodu architekta, są zasady odpowiedzialności za zobowiązania spółki.

Zasada ta sformułowana została w art. $95 \S 1$ K.s.h. i polega na tym, że partner nie ponosi odpowiedzialności za zobowiązania spółki powstałe w związku z wykonywaniem przez pozostałych partnerów wolnego zawodu w spółce, jak również za zobowiązania spółki będące następstwem działań lub zaniechań osób zatrudnionych przez spółkę na podstawie umowy o pracę lub innego stosunku prawnego, które podlegały kierownictwu innego partnera przy świadczeniu usług związanych z przedmiotem działalności spółki. 
Przedstawione uregulowania dotyczące zasad odpowiedzialności za zobowiązania w spółce partnerskiej związane są z przyjętym jej charakterem, jako formą prowadzenia działalności w celu wykonywania wolnego zawodu. Jest to ograniczony zakres odpowiedzialności za zobowiązania zaciągnięte przez innych partnerów.

Partner odpowiada za te zobowiązania, które związane są bezpośrednio z jego działalnością lub osób, którymi kieruje i które są mu podporządkowane. Przy przyjęciu tego typu rozwiązania przez ustawodawcę legła filozofia bezpośredniego łączenia z działalnością wykonywaną w ramach spółki partnerskiej możliwości popełnienia błędu „w sztuce” [Katner 2000].

Błąd „w sztuce” nie jest kategorią prawna, gdyż przepisy nigdzie nie zdefiniowały tej kategorii. Jest to więc pojęcie używane w teorii prawa i to także w sposób niejednoznaczny. Po analizie różnych podejść do tego pojęcia, należy dojść do wniosku, że błąd „w sztuce”, to nienależyte wypełnienie zobowiązania powstałego w związku z wykonywaniem wolnego zawodu (w tym architekta). Za błąd „,w sztuce” należy uznać każde działanie osoby świadczącej usługi profesjonalne, które uniemożliwia należyte spełnienie wobec klienta spółki, świadczenia określonego umową lub prowadzi do jego niewypełnienia [Asłanowicz 2004].

Przyjmując założenie, że z działalnością architektoniczną wiąże się duże ryzyko popełnienia błędu, a co za tym idzie świadczenia odszkodowawczego (niekiedy dużej wartości) - w przypadku prowadzenia działalności w innej formie organizacyjnej niż spółka partnerska, obowiązek zapłaty odszkodowania obciążałby również innych partnerów niemających nic wspólnego z konkretnym przedsięwzięciem.

Ograniczony zakres odpowiedzialności partnera za zobowiązanie zaciągnięte przez innych partnerów dotyczy wyłącznie wykonywania w ramach spółki wolnego zawodu. W odniesieniu do innych zobowiązań zaciągniętych przy prowadzeniu spraw spółki partnerskiej nie ma różnicy $\mathrm{w}$ prowadzeniu $\mathrm{z}$ innymi spółkami osobowymi. Za ten typ zobowiązania wszyscy partnerzy odpowiadają bez ograniczeń całym swoim majątkiem, solidarnie z pozostałymi partnerami i spółką.

Podobnie jak w innych spółkach osobowych prawa handlowego, odpowiedzialność osobista partnerów jest subsydiarna wobec odpowiedzialności spółki. Można to sprowadzić do prostej konstrukcji, że jeżeli w spółce jest majątek, to wierzyciel ma obowiązek sięgnąć do tego majątku, a dopiero w drugiej kolejności do majątku osobistego partnerów, jeżeli spółka majątku nie ma lub jest on niewystarczający na pokrycie zobowiązań.

Przedstawiony, a przyjęty w spółce partnerskiej model odpowiedzialności stanowi jej podstawową cechę konstrukcyjna, to właśnie ten element decyduje o atrakcyjności spółki partnerskiej i wyróżnia ją spośród innych spółek osobowych.

Zgodnie z ogólnymi zasadami prawa cywilnego do odpowiedzialności spółki partnerskiej i partnerów dochodzi wtedy, kiedy spełnione są przesłanki odpowiedzialności kontraktowej (umownej).

Aby doszło do odpowiedzialności musi wystąpić szkoda u kontrahenta spółki (wierzyciela) i spowodowanie jej przez niewykonanie lub niewłaściwe wykonanie umowy, a także związek pomiędzy błędem lub brakiem wykonania a szkodą. 
W odniesieniu do działalności architektonicznej może zaistnieć przykładowo sytuacja tego rodzaju, że przy sporządzaniu projektu architektonicznego, wykonujący go pominął szereg danych, które powinny być uwzględnione przy realizacji zamówienia, a które były mu znane i to spowodowało, że projekt nie jest możliwy do zrealizowania. Osoby świadczące usługi profesjonalne zobowiązane są do zachowania najwyższej staranności przy podejmowaniu działań na rzecz swoich klientów. W związku z tym za błąd w opracowaniu projektu architektonicznego uzna się każde postępowanie sprzeczne z ogólnie przyjętymi prawidłami wiedzy architektonicznej.

Ograniczona odpowiedzialność partnerów może być wyłączona. Partner może wyrazić zgodę na ponoszenie odpowiedzialności, pomimo że nie jest odpowiedzialny za błąd „W sztuce” (art. $95 \S 2$ K.s.h.). W praktyce może to mieć miejsce wtedy, kiedy spółkę partnerską tworzy znany na rynku usług profesjonalnych lider wraz z grupą bardzo niedoświadczonych i dysponujących skromnym majątkiem partnerów, nieposiadających własnej klienteli, natomiast potencjalni klienci spółki mogą żywić obawy, że powierzenie im bardziej skomplikowanych zleceń będzie połączone z nadmiernym ryzykiem w razie niewykonania lub nienależytego wykonania zobowiązań. Lider takiego zespołu może wówczas podjąć ryzyko ponoszenia pełnej odpowiedzialności w zamian np. za decydujący wpływ na zarządzanie spółką lub większy udział w zysku [Kiedyba 1999].

W spółce partnerskiej obowiązują regulacje podatkowe takie same, jakie znajdują odniesienie do wszystkich spółek osobowych. Zasady określone w tych regulacjach dotyczą przychodów i kosztów oraz okresów rozliczeniowych. W tej kwestii obowiązuje także orzecznictwo sądowe, jak chociażby rozstrzygnięcie Warszawskiego Sądu Administracyjnego sygn. akt II FSK 1364/11 26 marca 2013 r., czy wcześniejsze decyzje wojewódzkich sądów administracyjnych przy rozstrzygnięciu konkretnych spraw, jak chociażby Wojewódzkiego Sądu Administracyjnego w Kielcach 12 sierpnia 2011 r. I SA/Ka 329/10 czy Wojewódzkiego Sądu Administracyjnego w Warszawie 14 kwietnia 2009 r. III.SA/Wa 2926/08.

Uregulowania podatkowe jak i orzecznictwo sądowe pozwalają na sformułowanie wniosku, że w odniesieniu do zasad wnoszenia wkładów do spółki partnerskiej i zobowiązań podatkowych nie korzysta ona ze specjalnego traktowania w porównaniu z innymi spółkami, a więc w tym zakresie trudno mówić o specyfice spółki partnerskiej.

Kolejną zaletą spółki partnerskiej jest sposób zarządzania taką spółką. W innych spółkach osobowych prawa handlowego obowiązuje zasada włączenia do zarządzania i reprezentowania spółki na zewnątrz wszystkich wspólników z możliwością pewnych modyfikacji polegających na wyłączeniu niektórych wspólników. W analizowanej spółce istnieje możliwość ustanowienia zarządu spółki (art. 97 K.s.h). Powstanie zarządu nie ma charakteru obligatoryjnego, a tylko fakultatywny. Taka możliwość może działać na korzyść spółki w przypadku jej rozbudowanej struktury, wielu partnerów czy pracowników. W związku z tym, że członkami zarządu mogą być, oprócz partnerów, osoby z zewnątrz, istnieje realna szansa, że powołani do tego organu zostaną „fachowcy od zarządzania”, którymi nie zawsze są partnerzy wykonujący wolne zawody. O tym czy zarząd zostanie powołany zadecydować można w postanowieniach umowy spółki, jako podstawy jej działalności przy formułowa- 
niu jej treści lub w późniejszym terminie, dokonując odpowiedniego wpisu do Krajowego Rejestru Sądowego, w którym spółka jest zarejestrowana.

Zarząd ma kompetencje do prowadzenia wszystkich spraw spółki, chyba, że co innego postanowiono w umowie spółki. Zarząd reprezentuje spółkę na zewnątrz, inne postanowienia w umowie spółki wyłączające członków zarządu z reprezentacji spółki, a powierzające tę reprezentację partnerom są nieważne, chyba, że partner został pełnomocnikiem.

Oprócz możliwości powołania zarządu, partnerzy spółki partnerskiej mają prawo na podstawie art. 89 K.s.h. do innego ukształtowania stosunków wewnątrz spółki jak i na zewnątrz. Stosownie do brzmienia tego artykułu każdy partner ma prawo reprezentować spółkę samodzielnie, chyba, że umowa spółki stanowi inaczej. Nie jest wykluczone pozbawienie partnera prawa reprezentowania spółki jednak z zastrzeżeniem, iż musi tu chodzić o ważne powody i uchwała w tej kwestii musi być powzięta większością 3/4 głosów w obecności co najmniej 2/3 ogólnej liczby partnerów (art. $96 \S 2$ K.s.h.).

Przywołany art. 96 § 2 różni spółkę partnerską od innych spółek zarządzanych przez wspólników. Pozbawienie partnera prawa reprezentowania spółki przez nich samych stanowi specyfikę analizowanej spółki, gdyż w pozostałych spółkach osobowych uprawnienia takie posiada sąd.

Partner, który nie został pozbawiony prawa reprezentowania spółki, może ją reprezentować we wszystkich sprawach mieszczących się w zakresie działalności spółki. Stan taki wynika zarówno z uregulowań prawnych, jak i orzecznictwa sądowego, jak chociażby wyrok Wojewódzkiego Sądu Administracyjnego w Szczecinie I SA/Sz 760/07, Postanowienie z dnia 22 sierpnia 2008 r, Naczelny Sąd Administracyjny w Warszawie I FSK 832/08.

Podstawą funkcjonowania spółki partnerskiej jest umowa spółki i zgodnie z postanowieniami art. 91 K.s.h. powinna zawierać co najmniej treść określoną w tym przepisie. Dla tego typu spółek ważne jest określenie wolnego zawodu wykonywanego przez partnerów w ramach spółki, przedmiotu jej działalności, firmy i siedziby spółki, czasu jej trwania. W związku z tym, że zarządzać spółką mogą wszyscy partnerzy, niektórzy z nich lub zarząd - w umowie spółki ten sposób zarządzania należy szczegółowo określić, zwłaszcza wtedy, kiedy powołany został zarząd.

Powołanie zarządu jest odstępstwem od reguły obowiązującej w spółkach osobowych (istnienie zarządu wyręcza uprawnienia partnerów do zarządzania spółką), dlatego jego skład, sposób powołania i odwołania, a także zakres kompetencji, to ważne postanowienia umowy spółki [Wyciślak 2014].

Szczegółowy podział obowiązków partnerów w umowie spółki oraz zasad ich odpowiedzialności za zobowiązanie w odniesieniu do tej właśnie spółki ma znaczenie chociażby z uwagi na konieczność ich identyfikacji przy dochodzeniu odpowiedzialności przez kontrahentów spółki. Jak już wcześniej zostało to przedstawione, partner odpowiada za zobowiązania występujące w jego działalności, jak i podległych mu pracowników. W umowie spółki należy dokonać określenia, jakiego rodzaju usługi na rzecz klienta i których klientów ma dokonywać dany partner (np. projekty architektoniczne na rzecz osób indywidualnych, firm czy może jeszcze podmiotów uspołecznionych). Tego rodzaju postanowienia w umowie 
spółki mogą zapobiec wewnętrznym nieporozumieniom dotyczącym odpowiedzialności pomiędzy poszczególnymi partnerami.

W spółce partnerskiej, w ramach której wykonywane są wolne zawody, szczególnego znaczenia nabiera profesjonalne sporządzenie umowy, co w innych typach spółek nie ma takiej wagi.

Identyfikacja partnera odpowiedzialnego za błąd „w sztuce” dla wierzyciela może być trudna, jeżeli z umowy spółki nie wynika wyraźnie wskazanie, kto może być odpowiedzialny za wykonanie czy zaniechanie odpowiedniej czynności. W takiej sytuacji swoje roszczenia poszkodowany może kierować do samej spółki, a partnerzy niemający nic wspólnego z danym przedsięwzięciem razem ze spółką ponosiliby odpowiedzialność, tak jak w innych spółkach osobowych, całym swoim majątkiem.

Taki stan rzeczy byłby sprzeczny z fundamentalną zasadą przyjętą przy konstrukcji spółki partnerskiej, a mianowicie ograniczonej odpowiedzialności przez partnera.

Brak możliwości przypisania zindywidualizowanemu partnerowi odpowiedzialności, zdaniem niektórych zajmujących się tym zagadnieniem [Klatka 1998], stwarza trudności z przypisaniem konkretnemu partnerowi odpowiedzialności wynikającej z powstania danego zdarzenia, a to mogłoby zagrażać bezpieczeństwu obrotu gospodarczego. Aby uniknąć takich zagrożeń i w celu utrzymania wysokiej renomy spółki, partnerzy z reguły precyzyjne formują zakresy swojej odpowiedzialności w umowie spółki.

Umowa spółki partnerskiej zawiera także przyczyny jej rozwiązania stosownie do art. 98 K.s.h. Wśród nich zwrócić należy uwagę na taki powód rozwiązania spółki jak utrata przez wszystkich partnerów praw do wykonywania wolnego zawodu. Podkreślenia wymaga fakt, że przyczyną rozwiązania spółki, jest utrata uprawnień przez wszystkich partnerów. Spółka partnerska, jako spółka osobowa nie może funkcjonować, jako spółka jednoosobowa.

Regulując spółkę partnerska, Kodeks Spółek Handlowych, nie określa kwestii związanych z samym pojęciem „utraty uprawnień do wykonywania wolnego zawodu”. Tego rodzaju regulacje znajdują się w przepisach dotyczących wolnych zawodów i w związku z tym przy zakładaniu spółki partnerskiej należy i ten element wziąć pod uwagę, choć w praktyce utrata uprawnień do wykonywania zawodu, nie jest zbyt częsta.

Konstrukcja prawna spółki partnerskiej, jest również korzystna dla prowadzących w jej ramach działalność gospodarcza, w tym w sferze architektury, z punktu widzenia opodatkowania tego rodzaju spółek.

Spółka partnerska, jak już o tym była mowa, nie ma osobowości prawnej. Z punktu widzenia prawa podatkowego podatnikami są poszczególni wspólnicy tej spółki, a więc dochód z udziału w tej spółce podlega opodatkowaniu podatkiem dochodowym od osób fizycznych. Brak osobowości prawnej spółki partnerskiej pozwala jej unikać podwójnego opodatkowania składającego się na podatek od osób fizycznych i podatek od osób prawnych.

Stosownie do uregulowań ustawy podatkowej przychody z udziału w spółce niebędącej osobą prawna, ze wspólnej własności, wspólnego przedsięwzięcia, wspólnego posiadania lub wspólnego użytkowania rzeczy lub praw majątkowych u każdego podatnika określa się proporcjonalnie do jego prawa w zysku [Mądrzak 2001]. 
W świetle przytoczonego postanowienia wielkość przychodu przypadającego na podatnika określa się proporcjonalnie do jego prawa w udziale w zysku. Taką samą zasadę stosuje się przy określeniu kosztów uzyskania przychodu zysków i strat przypadających na partnera.

Wspólnicy spółki partnerskiej w umowie spółki określają prawo udziału w zysku w dowolnej proporcji i według niej będą rozliczane przychody, koszty uzyskania przychodu oraz straty z udziału w spółce. W razie braku takich postanowień w umowie spółki, przyjmuje się, że wspólnicy maja równe prawa do udziału w zysku spółki oraz jej stratach, i taka zasada rodzi również skutki podatkowe.

Obowiązujące przepisy nie dopuszczają możliwości stosowania innej proporcji do rozliczania przychodów, a innej do rozliczania kosztów uzyskania przychodu. Podkreślenia wymaga, że umowy między wspólnikami spółek osobowych nie mogą mieć wpływu na obowiązki podatnika, wynikające z bezwzględnie obowiązujących przepisów prawa podatkowego, w tym przypadku zasad ustalania przychodów i kosztów uzyskania przychodów przypadających na partnera w spółce partnerskiej, art. 8. Ustawy o podatku dochodowym od osób prawnych (Dz.U. 1992, nr 21, poz. 86 z późn. zm.).

Podsumowując całość zagadnień związanych z funkcjonowaniem spółek partnerskich, należy raz jeszcze powtórzyć, że jest to atrakcyjna forma prowadzenia działalności gospodarczej dla wykonujących wolne zawody, w tym zawód architekta. Ograniczona odpowiedzialność za zobowiązania może być modyfikowana przez postanowienia umowy spółki i zgodę wspólników na ponoszenie pełnej odpowiedzialności całym osobistym majątkiem. W obowiązującym stanie prawnym, zasady odpowiedzialności, co stanowi o istocie każdej spółki, to możliwość wyboru najkorzystniejszego dla partnerów sposobu ich odpowiedzialności w odniesieniu do ich konkretnej sytuacji.

Problemem może być, zawłaszcza dla wierzycieli spółki, wartość majątku partnerów oraz spółki, który stawiany jest do dyspozycji wierzycieli. Wartość zobowiązania może przekraczać wartość majątku spółki czy zobowiązanego do odpowiedzialności wspólnika.

Rozwiązaniem tego konkretnego problemu może być ubezpieczenie partnerów od odpowiedzialności związanej z prowadzoną działalnością i przeniesieniem konieczności realizacji zobowiązań na ubezpieczyciela. Stworzy to większe bezpieczeństwo dla klientów spółki, która stanie się bardziej wiarygodna.

Zaletą spółki partnerskiej jest również to, że partnerzy sami mogą podejmować decyzję dotyczącą sposobu zarządzania spółką. Oni sami podejmując określone decyzje mogą oddać to zarządzanie profesjonalistom powołanym do zarządu spółki, albo pozostawić je w rękach samych wspólników.

W związku z tym, że prowadzący działalność architektoniczną mogą prowadzić ją $\mathrm{w}$ różnych formach organizacyjno-prawnych, w tym także spółek kapitałowych, to jednak bezsprzecznie spółka partnerska stanowi dla nich formę optymalną. 


\section{Bibliografia}

Asłanowicz M., 1998a, Charakter prawny spółki partnerskiej, „Państwo i Prawo”, 7, s. 65-78.

Asłanowicz M., 1998b, Treść umowy spótki partnerskiej, „Przegląd Prawa Handlowego”, 12, s. 20-27.

Asłanowicz M., 2004, Spótka partnerska, LexisNexis, Warszawa.

Katner W., 2000, Kodeks spółek handlowych z wprowadzeniem, Warszawa.

Klatka Z., 1998, Spótka partnerska nowa forma wykonywania zawodu radcy prawnego, „Radca Prawny", 4 .

Mądrzak H., 2001, Pozycja osobowych spółek handlowych w postępowaniu cywilnym (na przykładzie spótki jawnej), [w:] R. Sztyk (red.), Kodeks spótek handlowych: studia i materiały, Poznań, s. $411-426$.

Kiedyba A., 1999, Spótka partnerska w prawie niemieckim i projekcie prawa spótek handlowych, „Prawo Spółek”, 9.

Sołtysiński S., Szajkowski A., Szumański A., Szwaja J., 2001, Kodeks spółek handlowych. Przepisy ogólne. Spótki osobowe, t. I. Komentarz do artykułów 1-150, C.H. Beck, Warszawa.

Wyciślak J., 2014, Spółki osobowe i ich opodatkowanie. Optymalizacja podatkowa spółek kapitałowych, C.H. Beck, Warszawa.

\section{Architectural activities in the form of a partnership}

\section{ABSTRACT}

The present paper has focused on the opportunity of starting and conducting architectural activities as limited liability company, taking into consideration its character. Such type of company is designed to carry out liberal professions. Carrying out a liberal profession (including profession of architect) is related to making mistake „in art”, which results in compensation, which is the obligation of the company.

In the company the liability for obligations takes into account the risk of error. The responsibility in the company has been positively regulated.

Basic conclusion included in the paper constitutes representation of the company as the most effective form of conducting architectural activities. 